\title{
Health Care Professionals' Pain in Pandemic COVID 19 in India
}

\author{
Ashok Kumar Rastogi ${ }^{1}$, Binay Kumar ${ }^{2}$, Avinash Kumar ${ }^{3}$, \\ Amrendra Kumar ${ }^{3}$, Prabhat Kumar ${ }^{3}$, Nawal Kumar Singh ${ }^{3}$, Himanshi ${ }^{4}$ \\ ${ }^{1}$ Assistant Professor, ${ }^{2}$ Associate Professor, ${ }^{3}$ Senior Resident, ${ }^{4}$ Senior Resident, \\ Department of Forensic Medicine \& Toxicology, All India Institute of Medical Sciences, Patna, Bihar
}

\begin{abstract}
Health care professionals are highly vulnerable for COVID 19 infection. It is due to frequents contact with COVID 19 positive patients, long time exposure with positive patients. There may be lack of personnel protective equipment's (PPE).Indian health care professional taking many kinds of pain during the management of COVID 19.it can be hospital related problems during management, professional must wear PPE about 06 hours on duty time. Duty time with PPE personnel uncomforted and cannot have anything even water. PPE cannot change frequently. Sociallypersons do not comfort because society not accepting as normal people,they afraid of spreading of corona by health care personnel. Family isolation also necessary for the health care professional to avoid infection to their family members during COVID 19 management. Healthprofessionals have tough time to managepandemic. Government also active and full swing supporting providing extra care of health professionals. giving insurance and approved extra budget to fight with COVID 19.
\end{abstract}

Keywords: COVID 19, PPE, Pandemic, Isolation.

\section{Introduction}

Whole world fighting with pandemic COVID 19, this word given by WHO in January 2020, COVID 19 indicate corona virus disease 2019, (COVID-19) was outbreak from Wuhan, China January2020. ${ }^{1}$ on 30 January 2020WHO declared outbreak of this disease and declare as Public Health Emergency globally. ${ }^{2}$ In India $1^{\text {st }}$ case of corona virus detected on $30^{\text {th }}$ January $2020^{3}$ and fist case of COVID 19 reported in December 2019 from Wuhan city from china. Total cases in India till date 08 April 2020 for COVID 19 is $\mathbf{4 7 1 4}$ Active Cases,410 Cured/Discharged, 149 Deaths 1 Migrated. ${ }^{4}$

\section{Corresponding Author:}

\section{Dr. Ashok Kumar Rastogi}

Assistant Professor, Department of Forensic Medicine \& Toxicology, All India Institute of Medical Sciences, Patna, Bihar

Contact No.: 9300030477

e-mail: ashokforensic@yahoo.com
Indian health professional including doctors and paramedical staff providing the health care services in all over the India. in India all places not the protective measure available and in some higher institute protective equipment's not in sufficient amount, ${ }^{5}$ we using these protective equipment cautionary as per the direction and availability of PPE . it should try make at local level by and low price, can make by raincoat/wind chitter material can be used. Scientific and technical approval can be taken. It should be in 3 layers, 1 st layer -made up of material like wind cheater, 2nd layer- Absorbent like foam, so that if any respiratory droplets passes through 1 st layer it gets absorbed in it, 3rd layer-again of the same material like the $1^{\text {st }}$ layer Hydrophobic: non porous: nonabsorbent. Devolved country also facing PPE kit shortage problem and India is developing country. Till 03 April in India about 50 health professionals affected by COVID $19 .^{6}$ This insist to think about the future of our health professional COVID 19 case increasing day by day in this COVID outbreak, if health professional become sick who will treat the COVID cases. Frequently screening for the corona of health professional is suggested, by 
this we can save our health professional and citizens. It is noted that $2339(8 \cdot 4 \%)$ health professional infected on $10^{\text {th }}$ march in Italy $^{7}$ and affected people are 115242 , no of death 13915 till $3^{\text {rd }}$ April in Italy. ${ }^{8}$ Availability of screening labs are also a problem in India in relation to population, very few labs are available for screening also an alarming for Indians.

There is lack of screening of health professional in India, many times health professional mainly infected by patients and during asymptomatic stage the health care infected many persons and other patients who comes to doctor for consultation. Asymptomatichealth professionals also affect their family members. This infection from patient to health professional and health professional to other patients by droplets through sneezing and coughing. ${ }^{9}$ first case infection one person to another person case reported in US in January 2020. ${ }^{10}$

The health professional who treating the admitted COVID 19 patientin the hospital, there must needed to personnel protective equipment's (PPE)wear during the treatment duty time. ${ }^{11}$ In PPEwhole body covered with impermeable leakproof dress which is uncomfortable. After wearing the PPE person cannot move here and there and not touch anything. once PPE wear, he has worn at least 6 hours till duty finished cannot changed dress frequently, after wearing significant amount of sweating and heat generated, in 06 hours significant amount sweating happen which can lead to dehydration and its complication. Its highly recommended personal protection of health care workers working for COVID 19 management. ${ }^{12}$ Which is horrible for the employee, uneasiness, and mental torture. During duty time employee does not use to eat anything even cannot drink water. Even having all protection during the COVID 19 management, chances of infection to the health professional not nil. Risk of infection for the health workers is seen. ${ }^{13}$ Death of health care professional also reported $1.1 \% .{ }^{14}$ Cases of infection in health care workers are due to long time exposure with large numbers of patient, inadequate numbers of PPE and inadequate training related to COVID 19 of health professionals. ${ }^{13}$ In china about $29 \%$ health professional infected by COVID 19 reported till date February 13 2020. ${ }^{15}$ Mental trauma of medical staff during COVID 19 management also reported. ${ }^{16}$ Health care professional not happily indulge in patient care but humanity sake and bound to do duty, sacrificing the himself to serve the nation and humanity.
Family related problems originated with the health care professional who are treating the COVID 19 patients. He avoids living with their family members because there are chances of spread of infection to their kin near and dear. That is health care professionals are worried about their family members and relatives. As we know that everyone has their family included kids to old members. study in china reported that it affects the all age group, $4 \%$ affected less than 17 years aged peoples, $12 \%$ cases seen in more than 65 years age rest $84 \%$ cases reported in middle aged 18 to 64 years age group population. ${ }^{17}$ in respect of family value, Two infected Italian nurses also committed suicide due fear of spreading of infection to the others. ${ }^{18}$

Society related problems also came to notice in the Indian society,the health care workers ruined by the peoples, disgraceful behaviour with health care providers. Some part of India reported that when health workers went into the society for the screening of COVID 19 cases. They started fighting with them and there was mob attack over the few health care providers. They save yourself by run away, that's life-threatening situation for the health care providers. ${ }^{19}$ health care professional residing at their home,those area public doing bad behaviour they are saying to health providers confined at your home do not move. Groceries shop keeper not supporting the health care providers not giving groceries to them and saying go away,you are more vulnerable to spread infection to us. Many health professionals are renters and their land lard insisting to vacate the house. They be afraid of that health professional can spread the COVID19 to others nearby.

Government giving full support to health care provider, who are indulging in management of COVID 19 casesas much as possible. In respect of this pandemic to fight with the situation, government given separate budget that's one lakh seventy thousandcrore. ${ }^{20}$ Other country also allocated separate budget to fight with COVID 19 tragedy, US allocation is two trillion US dollar to fight this pandemic ${ }^{21}$. In Indiagovt also approved insurance for health care providers to encourage the moral and family support. ${ }^{22}$ It will provide an insurance cover of Rs. 50 lakhs for ninety (90) days to a total of around 22.12 lakh public healthcare providers, including community health workers, who may have to be in direct contact and care of COVID-19 patients and who may be at risk of being impacted by this. It will also include accidental loss of life on account of contracting COVID-19. ${ }^{22}$ 
WHO considers 'airborne precautions' for medical staff after study shows coronavirus can survive in air. ${ }^{23}$ Management of the corpse with suspect, probable or confirmed COVID-19 respiratory infection - Italian interim recommendations for personnel potentially exposed to material from corpses, including body fluids, in morgue structures and during autopsy practice. ${ }^{24}$ Any post-mortem activities, from recovery, transport, to autopsies and handover to families and burial, should be therefore conducted with a focus on avoiding aerosol generating procedures, such as splashes of contaminated fluids $;{ }^{25}$ Forensic pathologists beware: COVID-19 lives on in blood after death.

\section{Conclusion}

Indian Health care professionals are in awfully bad and painful condition; beside that they are serving the nation and they are providing hope to live to the COVID 19 patients. Indian government also supporting as much as possible by all the way to fight with corona dragon. Health care professional fighting everywhere in hospital,society as well as their home with family and relatives.

Conflict of Interest: None declared

Source of Funding: None

Ethical Clearance: Not required (Review literature).

\section{References}

1. Wu JT, Leung K, Leung K, Bushman M, Kishore $\mathrm{N}$, Niehus R, et al. Estimating clinical severity of COVID-19 from the transmission dynamics in Wuhan, China. Nat Med Lett.2020;1-5. Available from: https://doi.org/10.1038/s41591-020-0822-7

2. Sohrabi C, Alsafi Z, O'neill N, Khan M, Kerwan A, Al-Jabir A, et al. World Health Organization declares global emergency- A review of the 2019 novel coronavirus (COVID-19). Int J Surg . 2020;76:71-6.

Available from: https://doi.org/10.1016/j. ijsu.2020.02.034

3. Wikipediaorg. Https://enwikipediaorg/wiki/ COVID-19_pandemic_in_India. Available from: https://en.wikipedia.org/wiki/2020

4. Government of india. India Fights Corona COVID-19.Available from: https://www.mygov. in/covid-19.
5. Dev, A.T.U.L. COVID-19: 'Panic' among India health workers over PPE shortages. Available from: https://www.aljazeera.com/news/2020/03/ covid-19-panic-india-health-workers-ppeshortages-200331075627594.html.

6. News India. India Reports Most Covid-19 Deaths in South-East Asia Region With Toll at 2,649. Available from: https:/www.news18.com/news/ india/is-this-how-we-treat-our-covid-19-soldiersmedics-across-india-battle-neglect-harassmentrape-threats-2562473.html.

7. Worldmotors. Italy corona virus cases. Available from: https://www.worldometers.info/coronavirus/ country/italy/.

8. Rothan HA, Byrareddy SN. The epidemiology and pathogenesis of coronavirus disease (COVID-19) outbreak. J Autoimmun.2020;102433. Available from: www.elsevier.com/locate/jautimm

9. CDC. CDC Confirms Person-to-Person Spread of New Coronavirus in the United States.Available from: https://www.cdc.gov/media/releases/2020/ p0130.

10. Holland M, Zaloga DJ, Friderici CS. COVID-19 Personal Protective Equipment (PPE) for the emergency physician. Vis J Emerg Med. 2020;19(March):100740. Available from: https:// doi.org/10.1016/j.visj.2020.100740

11. Wang J, Liu F, Tan JBX, Harbarth S, Pittet D ZW systematic review. Imple- mentation of infection prevention and control in acute care hos- pitals in Mainland China e a systematic review. Antimicrob Resist Infect Control. 2019;8(32).

12. Wang J, Zhou M, Liu F. Exploring the reasons for healthcare workers infected with novel coronavirus disease 2019 (COVID-19) in China. J Hosp Infect. 2020;2019-20.

13. World Health Organization. Report of the WHOChina Joint Mission on Coronavirus Disease 2019 (COVID-19). 2020. Available at: https://www. who.int/docs/default source/coronaviruse/whochina-joint-mission-on-covid-19-final-report.pd.

14. Secon, H.O.L.L.Y. More than 500 healthcare workers in Wuhan have gotten the coronavirus One study found that $29 \%$ of infections were in medical staff. Available from: https://www.businessinsider. $\mathrm{in} / \mathrm{science} /$ news/more-than-500-healthcareworkers-in-wuhan-have-gotten-the-coronavirusone-study-found-that-29-of-infections-were-in- 
medical-staff-/articleshow/74108681.cms.N

15. Li Z, Ge J, Yang M, Feng J, Qiao M, Jiang R, Bi J, Zhan G, Xu X, Wang L, Zhou Q, Zhou C, Pan Y, Liu S, Zhang H, Yang J, Zhu B, Hu Y, Hashimoto K, Jia Y, Wang H, Wang R, Liu C, Yang C, 2020. Vicarious traumatization in the general public, members and non-members of medical teams aiding in C-19 control. BBI pii: S-1591(20)303093. [Epub ahead of print]. Available from: https:// doi.org/10.1016/j.bbi.2020.03.00.No.

16. Zhang J, Litvinova M, Wang W, Wang Y, Deng $\mathrm{X}$, Chen X, et al. Articles Evolving epidemiology and transmission dynamics of coronavirus disease 2019 outside Hubei province, China : a descriptive and modelling study. Lancet Infect Dis. 2020;3099(20):1-10. Available from: http://dx.doi. org/10.1016/S1473-3099(20)30230-9

17. Montemurro N. Journal Pre-proofs The emotional impact ofCOVID-19: from medical staff to common people. Brain Behav Immun. 2020; Available from: https://doi.org/10.1016/j.bbi.2020.03.032

18. Shubhary. NSA Slapped Against Four Culprits Involved In Attack on Healthcare Workers In Indore.Available from: https://news.abplive.com/ news/india/nsa-slapped-against-four-culpritsinvolved-in-attack-on-healthcare-workers-inindore-1188220.

19. Merwin, R.A.D.H.I.K.A. Covid-19 stimulus package: Centre's Rs 17-lakh crore no match for global response. Available from: https:// www.thehindubusinessline.com/portfolio/newsanalysis/covid-19-stimulus-package-centres-rs17-lakh-crore-no-match-for-global response/ article31176067.ece.
Medico-legal Update, October-December 2020, Vol. 20, No. 4

20. Press trust of india. Covid-19: Trump signs \$2trn rescue package, largest-ever US stimulus bill. Available from: https://www.business-standard. com/article/international/covid-19-trump-signs2-trn-rescue-package-largest-ever-us-stimulusbill-120032800585_1.html.

21. The economic times. Government approves insurance scheme for health workers fighting COVID-19.Available from:https://economictimes. indiatimes.com/news/economy/policy/government approves-insurance-scheme-for-health-workersfighting-covid-19/articleshow/74875243.cms?

22. https://www.cnbc.com/2020/03/16/who-considersairborne-precautions-for-medical-staff-after-studyshows-coronavirus-can-survive-in-air.html.

23. Fineschi V, Aprile A, Aquila I, Arcangeli M, Asmundo A. Management of the corpse with suspect, probable or confirmed COVID-19 respiratory infection - Italian interim recommendations for personnel potentially exposed to material from corpses, including body fluids, in morgue structures and during autopsy pra. 2020;19.

24. Finegan O, Fonseca S, Guyomarc'H P, Morcillo Mendez MD, Rodriguez Gonzalez J, Tidball-Binz $\mathrm{M}$, et al. International Committee of the Red Cross (ICRC): General Guidance for the Management of the Dead Related to COVID-19. Forensic Sci Int Synerg. 2020;(PG-). Available from: http:// www.sciencedirect.com/science/article/pii/ S2589871X20300309NS 